\title{
The Reform of the Universal Jurisdiction in Spain
}

\author{
María Dolores Bollo ArocenA*
}

\section{DID PUBLIC INTERNATIONAL LAW REQUIRE THE REFORM CARRIED OUT BY MEANS OF LAW I/2OI4?}

Defending the fact that the reform carried out in March 2014 was the answer to a request coming from International Law, as suggested by the Spanish legislator in the Explanatory Memorandum of the Law I/20I4 ${ }^{\mathrm{I}}$, would oblige us to state that the legislation in force in Spain until then - not the old version of Article 23(4) of the Organic Law of the Judicial Power (LOPJ) passed in 1985, but the watered down version approved in $2009^{2}-$ exceeded what International Law allowed our country. Ultimately, such excess - if any- would obey to an interference in what should be understood as national jurisdiction matters of other states, or in other words, an attack to their sovereignty, something that, in my opinion, never happened.

However, the above mentioned Explanatory Memorandum notices something I fully agree with: "the extension of the Spanish jurisdiction beyond the Spanish territorial borders must be legitimated and justified by the existence of an international treaty" or, I would add, by an international or even institutional customary rule, "that contemplates or authorises it"' under any formula whatsoever. A few years ago my Master, Professor Quel López, and I pointed out something similar. It was regarding the inclusion of feminine genital mutilation in the list of offences of Article 23(4) LOPJ. We advised that the states are not free to increase the number of offenses subject to the principle of universal justice as they deem fit, because it depends on the existence of a basis or fundament within international law itself4. In a monograph that is a reference for all of us devoted to the study of this theme, Sánchez Legido stated that, today, the idea suggested by the Permanent Court of International Justice (PCIJ) in the judgment of the Lotus case is unacceptable, a judgment that, even then was passed by a very tight majority. It dealt with the absence of limits in the states' extraterritorial

Lecturer in Public International Law. University of the Basque Country, Spain. Email: mariadolores.bollo@ehu.es. This paper has been carried out and funded through the Research Project with the following reference: DER 20I2-35049, Ministry of Economy and Competitiveness.

I Cf. Spanish Official Gazette (BOE) 63, I4 March 2014, at 23016-2303I. In its second paragraph the Explanatory Memorandum of the Law points out that "reality has shown that nowadays universal jurisdiction can only be conceived from the limits and the requests of International Law". To what reality does the legislator refer? Which are those limits and requests of International Law that seemed to have been infringed by the law in force until then?

2 Cf. Organic Law (LO) I/2009, 3 November 2009, complementary of the Reform Law of Proceedings Legislation to implement the new Judicial Office, by which the LO 6/1985 is modified (BOE 266, 4 November 2009, at 92091-92092).

3 Perhaps that is what the legislator meant when he finished the sentence without much sense due to a colon present in between "the agreement of the international community".

4 Cf. M.D. Bollo Arocena and F.J. Quel López, "Balance del principio de justicia universal en el ordenamiento español (1996 - 2006)" in J.L. De Castro Ruano and G. Orueta Estibariz (eds.), Escritos de internacionalistas en bomenaje al profesor Iñaki Aguirre Zabala (Servicio Editorial UPV - EHU, Bilbao, 2007), at 199-22I. 
jurisdiction, as it is shown by the fact that both national legislations and international conventions delimit with utmost care the circumstances in which states can extend extraterritorially the jurisdiction of their courts. Such circumstance invites us to think that "their power to claim penal jurisdiction on events occurred abroad is not unlimited".

That being said, was the reform necessary in juridical terms? Was it demanded by International Law? In order to answer this question we should remember what Law I/2009 meant. Compared to the old version of Art. 23(4) LOPJ of 1985, which allowed exercising the jurisdiction over events and people not connected with Spain because the important thing was the nature and seriousness of the behaviours to be judged, the principle in force until March of 2014 was applied to a series of behaviours comprising war crimes, crimes against humanity and genocide, provided that two conditions were met: firstly, there had to be a link, a joint or a connection point with Spain being: a) the Spanish nationality of the victims, b) the presence of the alleged perpetrator in Spain or, c) the existence of any other relevant connection with our country. This last requirement had not been explained but, taking the references included in the judgment of the case of Guatemala of $25^{\text {th }}$ February 2003 by the Higher Court, it could be satisfied by means of cultural, historical, social, linguistic or juridical connections, among other ${ }^{6}$. Nevertheless, this was not enough and there was an additional requirement. No proceedings that may lead to a research and an effective pursue of punishable acts ${ }^{7}$ should have been filed by other country with jurisdiction or the International Court.

To sum up, since 2009 and in the moment in which the reform subject of this paper was processed, Spain was able to exercise its jurisdiction solely and exclusively over events or situations that had some relation with our country - because after the said reform, the mere fact that serious violations of the human rights occurred against helpless human beings was no longer a matter of our interest or, better, of our business - , and provided that no other court, either national or international, it was the same, had already initiated a proceeding that may mean a research and an effective pursue, as it has just been pointed out. In other words, a principle of universal justice of subsidiary application. Being this the actual situation of our system at the beginning of 2014, does anybody truly believe that international law demanded the express reform approved by our Parliament? Does anybody truly believe that the principle thus formulated violated International Law? Obviously, it might have been an annoying and unconformable principle... but that is another thing. ${ }^{8}$

\footnotetext{
Cf. A. Sánchez Legido, Jurisdicción universal penal y Derecho Internacional (Tirant monografías 30I, Valencia, 2004), at 3I.

Cf. Tribunal Supremo judgment 327/2003, 25 February 2003, twelfth juridical basis. Prof. Ferrer Lloret opposed to the use of vague criteria such as the ones included in the judgment of the High Court, and instead he noted other connections such as the victim's residence in Spain or his double nationality - panish and a third State's, even though the later was the one effective. J. Ferrer Lloret, "The principle of Universal Criminal Jurisdiction in Spanish Practice (2003-2009)", I5 SYbIL (20II) 63-I06, at 93, text available at http://www.sybil.es/documents/ARCHIVE/volis/Ferrer.pdf (accessed 4 September 2014).

In order to avoid repeating myself and for the sake of space economy, I shall refer to what I already stated then in connection with the reform of 2009: M.D. Bollo Arocena, "La reforma del art. 23.4 de la LOPJ: ¿el ocaso del principio de justicia universal?, 9 Anuario Español de Derecho Internacional Privado (2009) 64I-650.

8 Cf. section III titled "Los asuntos chinos, las presiones de Pequín y el procedimiento parlamentario", from Sánchez Legido's paper, which, in my opinion, synthesizes perfectly if not the only reason that led to the reform, at least the last straw that broke the camel's back that for many was already almost broken, A. Sánchez Legido, "El fin del modelo español de
} 
In this paper I shall mention a simple example that, in my opinion, can be used to illustrate what I intend to set forth. Taking now the new version of the universal justice principle: in accordance with the provisions of Article 23(4)(a) of the LOPJ, Spain shall only have jurisdiction to hear cases of war crimes, crimes against humanity and genocide committed abroad if the perpetrator is Spanish or if the alleged perpetrator, in spite of being a foreigner, usually lives in Spain or, if this is not the case, if he is in our country and we refuse extradition to a third state that may have requested it.

Was there any juridical reason obliging Spain to carry out a reform as the one performed in March 20I4? I stress term obligation because one thing is that Spain may have decided something like that among the different possible options and another thing is that the only option was the one permitted by the law. It is striking that the victim's Spanish nationality may be enough reason for Spain to exercise its jurisdiction as regards the terrorism acts occurred abroad -Article 23(4)(e)-, but the same circumstance is not enough anymore if we are talking about genocide, crimes against humanity or war crimes. We should remember that the reform carried out in 2009 did include that link or connection point as valid regarding the exercise of universal jurisdiction. Terrorism offers up to eight connection points justifying the jurisdiction of the Spanish courts, while in the case of genocide, crimes against humanity and war crimes there are only three. It is also striking that a Spanish victim of "violence against women and domestic violence" - Article 23(4)(I) LOPJ- has more possibilities that his cause may be heard in Spain than a victim of a war crime, a crime against humanity or a crime of genocide, because in the first case the simple presence of the alleged perpetrator in our country would be enough, while in the second case, taking into account the text of the provision, this would still be necessary in addition to Spain's refusal of extradition of that person to a third state that may have requested it.

Somebody may argue that in one case it is the existence of a clear conventional basis -Council of Europe Convention of IIth May $201 \mathrm{I}$ on preventing and combating violence against women and domestic violence-, and maybe inexistent in the other case -Convention on the Prevention and Punishment of the Crime of Genocide of 1948-, what justifies a measure as the one described, but to me that is not the reason. Furthermore, we must not lose sight of the fact that there are other sources of international law apart from the conventional source that could and should be taken into consideration. Under my perspective, international customary law supported at least the formulation of the principle of universal justice included in article 23(4) LOPJ after the reform of 2009, particularly regarding war crimes, crimes against humanity and genocide. ${ }^{9}$ What is the basis to make such statement? The clear agreement existing in international society regarding the need to end the impunity of some criminal behaviours, and particularly those I am referring to. It is shown by the fact that the International Community, through the UN Security Council, created two International

jurisdicción universal”, 27 REEI (20I4), at 5-8, text available at http://www.reei.org/index.php/revista/num27/articulos/finmodelo-espanol-jurisdiccion-universal (accessed 4 September 2014).

9 Cf. Resolution passed by the Institute of International Law in 2005 affirming that "universal jurisdiction is primarily based on customary international law". However, it would be interesting to know to which principle of universal justice does it refer, or in other words, under which conditions it can be applied (available at http://www.idiiil.org/idiE/resolutionsE/2005_kra_03_en.pdf, accessed 4 September 2014). 
Criminal Courts - for the former Yugoslavia and for Rwanda - and with other specificities, the Special Court for Sierra Leona, and, of course, it must also be mentioned, the permanent International Criminal Court has been created for them. In spite of all its limitations, this permanent court unites 122 states around its creating statute. Some may answer to this remark that international courts and national courts are different things and, of course, I am aware of it. However the deep conviction existing in the international society of the need to cooperate to end impunity precisely in those cases cannot be denied. And a way to cooperate to stop impunity is to increase the range of possibilities to exercise jurisdiction. Besides, it is not correct to argue that given the existence of an ICC there is no point in applying the principle of universal justice to such offenses, because we all know that the ICC has a complementary jurisdiction - the responsibility to stop impunity still belongs to the states-, temporarily limited-events prior to July 2002 are automatically out of its range-, and, apart from exceptional cases - situation referred by the Security Council- its jurisdiction depends on its being part of the treaty, the territorial state or the state of the perpetrator's nationality.

Therefore, in my opinion, the reform carried out in March 2014 was not at all a compulsory reform because I do not think that the formulation of the universal justice principle in force until then in our system - it should be remembered that it was a principle applied at a subsidiary level and provided that there was some connection point with our country- represented an interference in the national affairs of third states or an attack to their sovereignty. Finally, I do not think either that it constituted an infringement of any provision of the international legal order.

\section{DOES THE REFORM APPROVED BY THE SPANISH PARLIAMENT IN MARCH 2014 CONSTITUTE A VIOLATION OF ONE OR SEVERAL INTERNATIONAL OBLIGATIONS?}

Defending that the reform was not an obligation is different from affirming, without any other precision, that it violates International Law, meaning that by approving the reform Spain ceases to meet the international obligations validly accepted, regardless of their kind. To reach that conclusion we must spin the fine details, and specify in which cases Spain could incur in international liability and why, above all taking into consideration how case-based is this current Article 23(4) of the LOPJ, because it includes no more and no less than 16 sections - letters a) to p) - referring to an even greater number of behaviours regulated by different international instruments, many of them conventional, but also of another nature, with different application conditions in each case.

Given the extension I have in this paper, I shall only focus on the existing situation in relation to some of the behaviours appearing in Article 23(4), and the most interesting and polemic ones from a practical and media point of view, because they are authentic international crimes, especially in need of punishment to protect the values shared by the International Community as a whole. I am referring to the ones included in section a) of Article 23(4) LOPJ: war crimes, crimes against humanity and genocide.

The powers granted by International Law to the states when it comes to establishing the rules to claim the jurisdiction to hear some criminal behaviour are different from the obligations imposed by 
International Law. If international Law only empowers states to do something, and from that range of possibilities the Spanish State, through its legislation, chooses one of them, there would not be any violation of an international obligation. The answer would be different if the law infringed an international obligation accepted by Spain. So, let us focus on the obligations accepted by our country concerning the criminal behaviours to which we are referring.

\section{(I) War Crimes}

The fact that the serious infractions of the Geneva Conventions and Additional Protocol I are led by the principle of universal justice is not a matter of much debate, because the provisions regulating this matter are forceful: "Each High Contracting Party shall be under the obligation to search for persons alleged to have committed, or to have ordered to be committed, such grave breaches, and shall bring such persons, regardless of their nationality, before its own courts. It may also, if it prefers, and in accordance with the provisions of its own legislation, hand such persons over for trial to another High Contracting Party concerned, provided such High Contracting Party has made out a prima facie case". ${ }^{\text {Io }}$ A non forced interpretation of the provision's text suggests the existence of an obligation to, firstly, search for the alleged perpetrators in their own territory, not in any part of the world ${ }^{\mathrm{II}}$, and, secondly, in case of finding them, proceed to their trial or, in case of receiving an extradition request from a third state, hand them over. But as the remark to Article 9 of the Draft Project on Crimes against the Peace and Safety of Mankind approved by the International Law Commission (ILC) in 1996 pointed out "in the event of not having an extradition request, the detention State shall have no other option than subjecting the matter to its national authorities in order to exercise criminal proceedings". ${ }^{\text {I2 }}$

Well, maybe the regulation included in the current Article 23(4)(a) of LOPJ does not cover fully Spain's international obligations to which I have referred. What would happen if an alleged war criminal was found in our country, but no state requested his extradition? Strictly speaking, the Article 23(4)(a) requires the presence of the alleged criminal in Spain and our denial to his extradition. The issue of the extradition would be irrelevant if instead of "being" in Spain he had his usual residence in Spain. But, what if it that was not the case? In my opinion, Article 23(4)(a) on paper, as regards war crimes, could present situations in which Spain may fail to fulfil its obligations under the

ro Cf. Art. 49, 50, I28 and I45 of I, II, III and IV Geneva Conventions respectively (adopted I2 August I949, entered into force 2I October 1950), as well as art. 85 of Additional Protocol I (adopted 8 June 1977, entered into force 7 December 1978).

II In my opinion States are obliged to search for the alleged war criminals inside their sovereign borders, not beyond, because otherwise there would be an overlap of obligations between all the States member of the Geneva Conventions without much sense. Therefore, the search obligation would be limited to their own territory, although the States would have the power to search beyond. Cf. The defence of the obligation to search in any part of the world in M. Abad Castelos. "La persecución restringida de los delitos que lesionan valores esenciales de la Comunidad Internacional: ¿sigue existiendo la jurisdicción universal en España?”, Is Revista de Filosofía, Derecho y Política (January 2012) 65-90, at 74, available at http://earchivo.uc3m.es/bitstream/handle/I00I6/I3385/abad_RU_20I2.pdf?sequence=I (accessed 4 September 20I4); I. Blanco Cordero, "La jurisdicción universal en España: un paso en la lucha contra la impunidad", in A.I. Pérez Cepeda (Dir.), El principio de justicia universal: fundamentos y límites (Tirant Monografías 813, Valencia, 2012) 559, at 582-583.

I2 Cf. paragraph 7th of the comments to Art. 9 in Report of the Commission to the General Assembly on the work of its forty-eight session (6 May- 26 July 1996), Yearbook of International Law Commission 1996, Volume II- Part Two, at. 35. 
Geneva Conventions, unless such gap could be covered using the provision of section p) of Article 23(4) LOPJ, or unless it is deemed that the conventional provisions mentioned are self-executive and, therefore, an adequate basis for the Spanish judges to apply the principle of universal justice as it is provided in the treaties.

In fact, section p) of Article 23(4) LOPJ works as a hotchpotch, because it establishes that also Spanish courts shall have jurisdiction over "any other crime whose pursue may be imposed compulsorily by a Treaty in force for Spain or by other ruling instruments of an International Organisation to which Spain may belong, in the circumstances and the conditions determined thereby". We could interpret that the section we have just transcribed can cover the international obligations, both conventional and institutional -it does not mention customary obligations - that are not considered in the previous sections of Article 23.4 of LOPJ. In that regard, we could refer to section $\mathrm{p}$ ) to cover the circumstance of the presence in Spain of an alleged war criminal whose extradition has not been requested by any state. In that event, in accordance with Article 23.4, section a), we could not exercise our jurisdiction, because the extradition would not have been refused by us, but we would have jurisdiction in accordance with section p), in relation to Articles 49, 50, I29 and I46 of the I, II, III and IV Convention respectively, as well as Article 85 of Additional Protocol I. If this interpretation is not admitted - understanding that the reference to "any other offence" appearing at the beginning of section p) would indicate an offence different from the ones mentioned in the previous sections, therefore, also different from war crimes-, we consider that the self executing nature of the said articles could be defended. As a result our national Spanish judge could refer to them directly with the purpose of substantiating his jurisdiction over those offences and avoiding Spain's failure to fulfil its international obligations.

\section{(2) Genocide and Crimes Against Humanity}

The Convention to prevent and punish the crime of genocide establishes the duty of the states to prevent the commission of genocide acts and to punish the perpetrators in the event that such actions take place. With reference to the exercise of the jurisdiction, the Article VI of the Convention points out that "Persons charged with genocide or any of the other acts enumerated in Article 3 shall be tried by a competent tribunal of the State in the territory of which the act was committed, or by such international penal tribunal as may have jurisdiction with respect to those Contracting Parties which shall have accepted its jurisdiction". Consequently, the convention considers jurisdiction either of a territorial state or an International Criminal Court if it has jurisdiction to hear the matter. It states nothing on the courts of other states, or the court of the criminal's country, or the victim's, or a third party's acting on the basis of universal justice. Does that mean that the states member of the Convention would be violating international law if they submitted the crime of genocide to the principle of universal justice? In my opinion they would not. For instance, the ILC has already defended the same position, or the Constitutional Court itself in the case of Guatemala. ${ }^{13}$ However,

\footnotetext{
13 Already in 1996 in the comments to Article 8 of the Draft Code of Offences against the Peace and Security of Mankind, the ILC pointed out that international customary law recognised the existence of the principle of universal justice regarding genocide. Cf. equally 5th juridical basis, Tribunal Constitucional judgment 237/2005, 26 September 2005 when it
} 
we cannot affirm either that the legislator has violated any conventional obligation due to the subjection of the principle of universal justice to limits or conditions when it is applied to genocide. And I think that we must draw the same conclusion regarding the crimes against humanity given that we lack a conventional instrument to define it autonomously, and, as a result, to establish some specific conditions to exercise the extraterritorial jurisdiction with regard to the same. It would be a different matter if the Spanish legislator was violating not just a conventional obligation but a customary obligation.

Does current Article 23(4)(a) violate any customary international obligation in relation to crimes against humanity and genocide? It is not easy to answer affirmatively to that question, if we apply strictly the definition of customary rule, i.e., general, constant, uniform and lasting practice carried out with the conviction of acting in compliance with an international obligation. The IDI in the resolution approved in Krakow in 2005, of which C. Tomuschat was rapporteur, stated that the principle of universal justice "est fondée en premier lieu sur le droit international coutumier". ${ }^{4}$ But, which are the specific profiles, i.e. the conditions to apply the principle of universal justice accepted by all, not as a power but as an obligation for the states? We insist that this is difficult to determine outright. If we remember, the Article 8 of the Draft Code of Crimes against the Peace and Safety of Mankind passed by the ILC in 1996 stated the obligation of the states to adopt necessary measures to establish their jurisdiction over the international crimes to which we are referring constantly, "wherever they were committed and whoever their perpetrators were", but it does not specify anything else regarding the application conditions. Nevertheless, Sánchez Legido is right when he points out that "it is difficult to deny that in the international practice there are enough elements to affirm the existence of an opinion iuris generalis"s in favour of applying the principle aut dedere aut judicare to the analysed crimes. For instance, we could mention the above mentioned provision of

points out that the Convention's silence on genocide must not be understood as a prohibition. However it is contradictory with the treaty's purpose understanding that the States member of the Convention would have waived a pursuit mechanism that could be used by non members, above all taking into account the long lasting inexistence of an International Criminal Court and the usual inefficiency of the territorial state's courts in these cases.

${ }^{14}$ Cf. Section two. In section three of the resolution, the Institute of International Law (IIL) pointed out: a) that universal jurisdiction is applied to international crimes such as genocide, crimes against mankind, serious violations of the Geneva Conventions and other serious violations of international humanitarian law committed in times of war conflict, either national or international; b) leaving aside the research proceedings and the extradition requests, the requirement of the presence of the alleged perpetrator in the State's territory that intends to exercise the jurisdiction; c) the implicit recognition of the subsidiary nature of the principle since it establishes the need to suggest the States with any connection with the events, that they should be the ones exercising the jurisdiction, i.e. territorial state, state of the perpetrator's nationality, provided that they have the will and capability to carry out his or her trial; $d$ ) and in relation to the above statements, the consideration on the side of the State intending to exercise the universal jurisdiction of the possibility to grant extradition to the State with some connection with the events and that has requested it. Cf. Resolution adopted on the 26th August 2005, supra n. 9. In a similar way, the International Association of Penal Law (IAPL) approved another resolution connected to the universal justice principle in the meeting held in Istanbul between 20-27 September 2009, coinciding in some points with the main points of the IIL: acceptance of "research actions" in revelry (submission of criminal proceedings, research, evidence assurance, accusation or extradition requests), but not the process itself when the basis of the jurisdiction is the principle of universal justice (section III of the Resolution). Cf. Text of the Resolution in <http://www.penal.org/IMG/pdf/NEP_23_esp.pdf>, at. 247 (accessed 3 September 2014).

Is Cf. the arguments set forth by Sánchez Legido in "El fin del modelo español de jurisdicción universal", supra n. 8, at 37-38. 
article 9 of the Draft of the ILC. It recognised that the principle aut dedere aut judicare is also applied to crimes against humanity and genocide, as well as to some infractions of the Geneva Conventions different from the serious ones, implying that, the state in whose territory there is a person allegedly responsible of such behaviours, either he is submitted to trial or extradited if it has been requested, but the obligation to a trial still exists if the last option does not take place - the obligation does not appear when the extradition is denied but due to the mere presence of the alleged offender in the state's territory. This being said is it possible to cover such customary obligation, to some extent, in view of the current writing of the Art. 23(4)(a) of the LOPJ? In my opinion, now it is more difficult to give a positive answer because section $\mathrm{p}$ ) - which served us as a possible resource to fill the void in the case of war crimes - refers to the obligations derived from conventional and institutional rules, but not to the ones derived from customary law, which, in this case, are equally self executing in so far as we are referring to a procedure rule that assigns the jurisdiction.

\section{HAS IT BEEN A CONVENIENT OR AN UNAVOIDABLE REFORM DUE TO NON-LEGAL REASONS?}

After all that has been set forth throughout these pages, my obvious conclusion is that, from a strictly legal point of view, the reform could have been avoided. But, was it a convenient reform? It all depends on the point of view from which that convenience is analysed. If we are talking about convenience regarding the stability of diplomatic and economic relations with third states, especially with the greatest powers, the answer is yes, the reform was convenient. Because, as I am aware, answering no with the deep crisis the country is undergoing is not politically correct, and it might be quite a naïve answer. However, if we are talking about convenience in other terms, terms of respect for the human rights, justice and fighting against impunity, and even about peace, the answer to the question would be, in my opinion, a categorical no. And that is the position I am taking because I consider that, if we believe it, it is necessary to keep defending, even from the University, the legal arguments and of other nature that exist to defend the principle of universal justice, at least in its watered down version of November 2009. And I am saying at least because I do not think that the old version of Article 23(4) of LOPJ, as it was passed in 1985, constituted any violation of the international law, as our Constitutional Court pointed out in the sentence 237/2005 when it advised that both the requirement of the presence of the alleged perpetrator of an international crime and the requirement of any other connection with our country (perpetrator's or victim's nationality, for example), were "clearly contrary to the purpose of the institution, which is altered to the point of making the principle of universal jurisdiction unrecognisable as it is conceived by international law and has the effect of reducing the scope of the precept to almost a de facto derogation of Article 23(4) LOPJ". ${ }^{16}$ The principle of universal justice, applied to the core of offenses we have referred to finds its

16 Cf. Tribunal Constitucional judgment 237/2005, legal basis 7-8. In a similar sense, Principios de Princeton sobre la jurisdicción universal, principles I.2 and I.3, available in UN Doc. A/56/677, Oral note 27 November 200I, addressed to the General Secretary of the Permanent Missions of Canada and the Netherlands before the United Nations; A. Remiro Brotóns, "Crímenes internacionales, jueces estatales: de la universalidad y otras soledades", in Guerra y Paz: 1945-2009. Obra bomenaje al Dr. Santiago Torres Bernárdez (Servicio Editorial de la UPV/EHU, Bilbao, 2010) 253, at 256-257. Due to all of 
purpose in the special nature of the actions themselves, crimes that endanger the peace and the safety of mankind and not the particular interests of a specific state. ${ }^{17}$ Therefore we do not consider essential the requirement of a connection point, not even the presence of the alleged perpetrator in the Spanish territory, because resources as extradition ${ }^{18}$ exist for such reason. I shall resume something that Professor Abad used to say regarding the reform carried out in 2009, more valid than ever after the reform of 2014, "this reform, in so far as it restricts the victims' right to access to jurisdiction, introduces in its turn a regression in the fulfilment of the right to truth, justice and reparation in terms of flagrant violations of the human rights and serious infractions of international humanitarian law". ${ }^{19}$ Maybe before the victims' expectations were not fully satisfied, but they will be even less fulfilled if the doors are deliberately closed for third states to exercise jurisdiction, knowing as we do, we are well aware of that, the scarce success of processes in the headquarters of the territorial state. ${ }^{20}$ In this regard, we must remember how satisfactory it was for many victims, and for the defenders of the human rights in general, the background, the lesson and the advances in the fight against impunity that meant a process such as the Dictator Augusto Pinochet's, although the case was filed once the British authorities decided not to extradite him to our country.

It is true that the states that had led the cause of the human rights protection allowing their courts to exercise their jurisdiction extraterritorially, have decided to retreat from that front line. ${ }^{2 I}$ It is not because international law requests it, but because they want to protect themselves from the damages that such position implies. However, that is not a legal requirement but another thing.

this, I keep defending that the version originally approved by Article 23(4) LOPJ in 1985 did not violate any international obligation.

${ }_{17}$ Cf. the interesting paper and the proposal of the Convention suggested by F. Jiménez García y B. García Sánchez, "Propuesta de Convención universal sobre el principio de justicia universal: algunas reflexiones", in A.I. Pérez Cepeda, (Dir.), El principio de justicia universal: fundamentos y límites (Tirant monografías 813, Valencia, 20I2) 179, at. 227.

${ }_{18}$ On the contrary, defending the principle of territorial universal justice, cf. J. Ferrer Lloret, "The principle of Universal Criminal Jurisdiction in Spanish Practice (2003-2009)", supra n. 6, at I03.

19 Cf. M. Abad Castelos, "La persecución restringida de los delitos que lesionan valores esenciales de la Comunidad Internacional: ¿sigue existiendo la jurisdicción universal en España?”, supra n. II, at 87.

20 According to some representatives of the Spanish Popular Party, apparently that was the real reason of carrying out the reform; and also complying with the requirements of international law... Cf. the paper of J. Chinchón Álvarez, whose title sets forth, precisely, what we have just highlighted "Del intento de acabar con la jurisdicción universal para el bien de las víctimas y del Derecho Internacional: examen crítico de la Ley Orgánica I/20I4, de 13 de marzo, de modificación de la Ley Orgánica (...) del Poder Judicial, relativa a la justicia universal...”, 5 Derecho Penal y Criminología (June 2014) 161-173.

${ }_{21}$ Cf. paper of Sánchez Legido to see the successive reforms of the principle of universal justice in different countries in "El fin del modelo español de jurisdicción universal", supra n. 8, at I3-I9. 